\title{
Primary extramedullary plasmacytoma of the sigmoid colon with perforation: a case report
}

\author{
Fumimasa Kitamura ${ }^{1 *} \mathbb{D}$, Koichi Doi ${ }^{1}$, Hiroyuki Ishiodori ${ }^{1}$, Tetsufumi Ohchi ${ }^{1}$ and Hideo Baba ${ }^{2}$
}

\begin{abstract}
Background: Extramedullary plasmacytomas account for $4 \%$ of all plasma cell tumors and occur mainly in the upper respiratory tract; gastrointestinal system involvement is rare. Extramedullary plasmacytoma of the colon with perforation has not been reported.

Case presentation: A 77-year-old woman with a 1-year history of lower abdominal pain and nausea was admitted to our hospital. An abdominal computed tomography scan revealed a sigmoid tumor with perforation. The patient underwent emergency surgery. Pathological examination led to a diagnosis of plasmacytoma of the colon. The patient did not undergo postoperative adjuvant chemotherapy. She has had no recurrence in 14 months of regular follow-up.

Conclusions: We have herein described a rare case of extramedullary plasmacytoma of the gastrointestinal tract with perforation involving the sigmoid colon.
\end{abstract}

Keywords: Extramedullary plasmacytoma, Colon neoplasms, Perforation

\section{Background}

A plasma cell tumor is an immunoproliferative monoclonal disease of the $\mathrm{B}$ cell line that originates from malignant transformed plasma cells. Plasmacytoma includes solitary plasmacytoma of bone and solitary extramedullary plasmacytoma.

Solitary extramedullary plasmacytoma has been rarely reported, and its natural history and diagnosis are unclear. Most such plasmacytomas occur in the nasopharynx or upper respiratory tract; only $10 \%$ of reported cases have involved the gastrointestinal tract. The stomach and small intestine are the most commonly involved sites in the gastrointestinal tract [1-3]. Primary isolated extramedullary plasmacytoma of the colon is extremely rare. No previous reports have described plasmacytoma of the colon with perforation. We herein report a rare case of primary isolated extramedullary plasmacytoma of the colon with perforation and describe the patient's postoperative clinical course.

\footnotetext{
* Correspondence: fumimasakitamura@yahoo.co.jp

'Department of Gastroenterological Surgery, Nobeoka Hospital, 2-1-10

Shinkoji, Nobeoka, Miyazaki 882-0835, Japan

Full list of author information is available at the end of the article
}

\section{Case presentation}

A 77-year-old woman with a 1-year history of lower abdominal pain and nausea was admitted to our hospital. Blood examination showed evidence of an inflammatory response (Table 1), and abdominal computed tomography revealed a sigmoid tumor with perforation (Fig. 1). We suspected sigmoid cancer with perforation, and the patient underwent emergency surgery. Open laparotomy revealed an extensive mass involving the sigmoid colon with surrounding contamination (Fig. 2). The abdominal mass was removed en bloc, including resection of the sigmoid colon. The abdomen was flushed to remove contamination. An artificial anus was made.

Histopathologic examination showed that the oval mass was composed of a diffuse proliferation of plasma cells (Fig. 3a). At the concavity of the site of the perforation showed the tumor cell infiltrated into the subserosa and necrosis of tissue. But we were unable to identify the site of the perforation pathologically. The surgical margins were free from tumor cells. Immunohistochemical examination revealed positivity for CD79a (Fig. 3b), immunoglobulin G, and lambda light chain (Fig. 4a, b). Other markers (CD10, CD20, and kappa light 
Table 1 Blood examination

\begin{tabular}{|c|c|c|c|c|c|}
\hline \multicolumn{2}{|l|}{ Blood count } & \multicolumn{2}{|c|}{ Biochemical parameters } & \multicolumn{2}{|c|}{ Coagulation parameters } \\
\hline WBC & $8090 / \mu \mathrm{L}$ & $\mathrm{TP}$ & $3.5 \mathrm{~g} / \mathrm{dL}$ & PT (s) & 14.3 \\
\hline $\mathrm{RBC}$ & $360 \times 10^{4} / \mu \mathrm{L}$ & Alb & $1.59 \mathrm{~g} / \mathrm{dL}$ & PT (\%) & 63.3 \\
\hline $\mathrm{Hb}$ & $11.5 \mathrm{~g} / \mathrm{dL}$ & T-bil & $1.19 \mathrm{mg} / \mathrm{dL}$ & PT-INR & 1.21 \\
\hline \multirow[t]{5}{*}{ Plt } & $21.4 \times 10^{4} / \mu \mathrm{L}$ & AST & $28 \mathrm{IU} / \mathrm{L}$ & APTT (s) & 45.4 \\
\hline & & ALT & $18 \mathrm{IU} / \mathrm{L}$ & ATIII & $49 \%$ \\
\hline & & ALP & $127 \mathrm{IU} / \mathrm{L}$ & FDP & $40.0 \mu \mathrm{g} / \mathrm{mL}$ \\
\hline & & LDH & $219 \mathrm{IU} / \mathrm{L}$ & D-dimers & $18.20 \mathrm{ng} / \mathrm{mL}$ \\
\hline & & $\gamma$-GTP & $14 \mathrm{IU} / \mathrm{L}$ & & \\
\hline Tumor markers & & BUN & $15.6 \mathrm{mg} / \mathrm{dL}$ & & \\
\hline CEA & $1.6 \mathrm{ng} / \mathrm{mL}$ & $\mathrm{Cr}$ & $0.4 \mathrm{mg} / \mathrm{dL}$ & & \\
\hline \multirow[t]{3}{*}{ CA19-9 } & $5.2 \mathrm{U} / \mathrm{mL}$ & $\mathrm{Na}$ & 134 mEq/L & & \\
\hline & & $\mathrm{Cl}$ & $3.6 \mathrm{mEq} / \mathrm{L}$ & & \\
\hline & & CRP & $29.49 \mathrm{mg} / \mathrm{dL}$ & & \\
\hline
\end{tabular}

WBC white blood cells, $R B C$ red blood cells, $H b$ hemoglobin, Plt platelets, CEA carcinoembryonic antigen, CA19-9 cancer antigen 19-9, $T P$ total protein, $A / b$ albumin, $T$-bil total bilirubin, AST aspartate transaminase, $A L T$ alanine transaminase, $A L P$ alkaline phosphatase, $L D H$ lactate dehydrogenase, $\gamma$-GTP gamma glutamyl transferase, $B U N$ blood urea nitrogen, $\mathrm{Cr}$ creatinine, Na sodium, $\mathrm{Cl}$ chloride, CRP C-reactive protein, $P T$ prothrombin time, $P T$-INR prothrombin time-international normalized ratio, APTT activated partial thromboplastin time, ATIII antithrombin III, FDP fibrin degradation products

chain) were negative (Fig. 4c). Pathological examination led to a diagnosis of plasmacytoma of the colon. The patient underwent bone marrow biopsy and bone imaging to exclude associated multiple myeloma. Her peripheral blood smear, serum protein electrophoresis, and urine immunoelectrophoresis for Bence-Jones protein were normal.

Postoperatively, the patient was discharged without any complications. She did not undergo postoperative adjuvant chemotherapy and has had no recurrence in 14 months of regular follow-up.

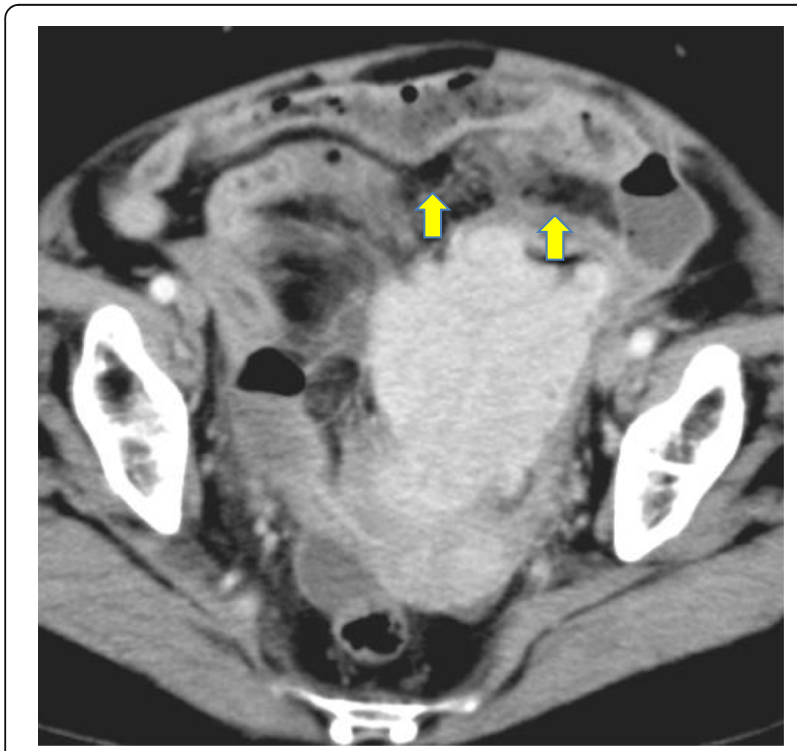

Fig. 1 Plain abdominal computed tomography. Huge tumor is present at the sigmoid colon, and free air (arrows) is seen around the tumor

\section{Discussion}

Extramedullary plasmacytoma accounts for only 3 to $5 \%$ of all plasma cell diseases. These tumors may be solitary or may precede, accompany, or follow the onset of multiple myeloma. Solitary extramedullary plasmacytoma has rarely been reported, and its natural history and diagnosis are unclear. Diagnosis of solitary extramedullary plasmacytoma requires the exclusion of associated multiple myeloma, which is determined by the absence of Bence-Jones protein in the urine, normal serum

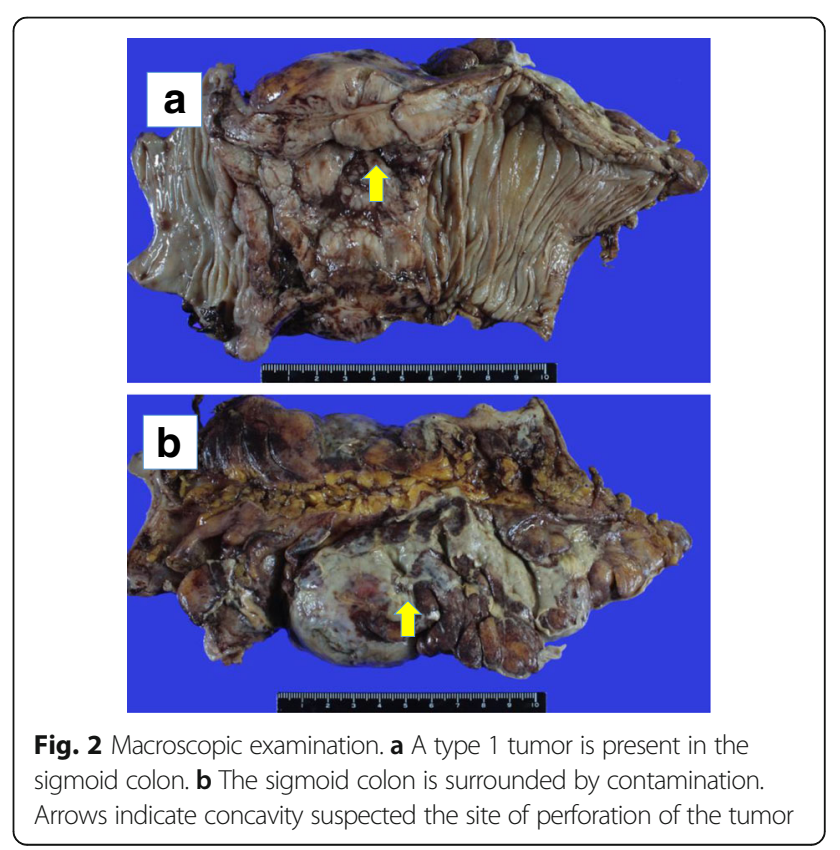




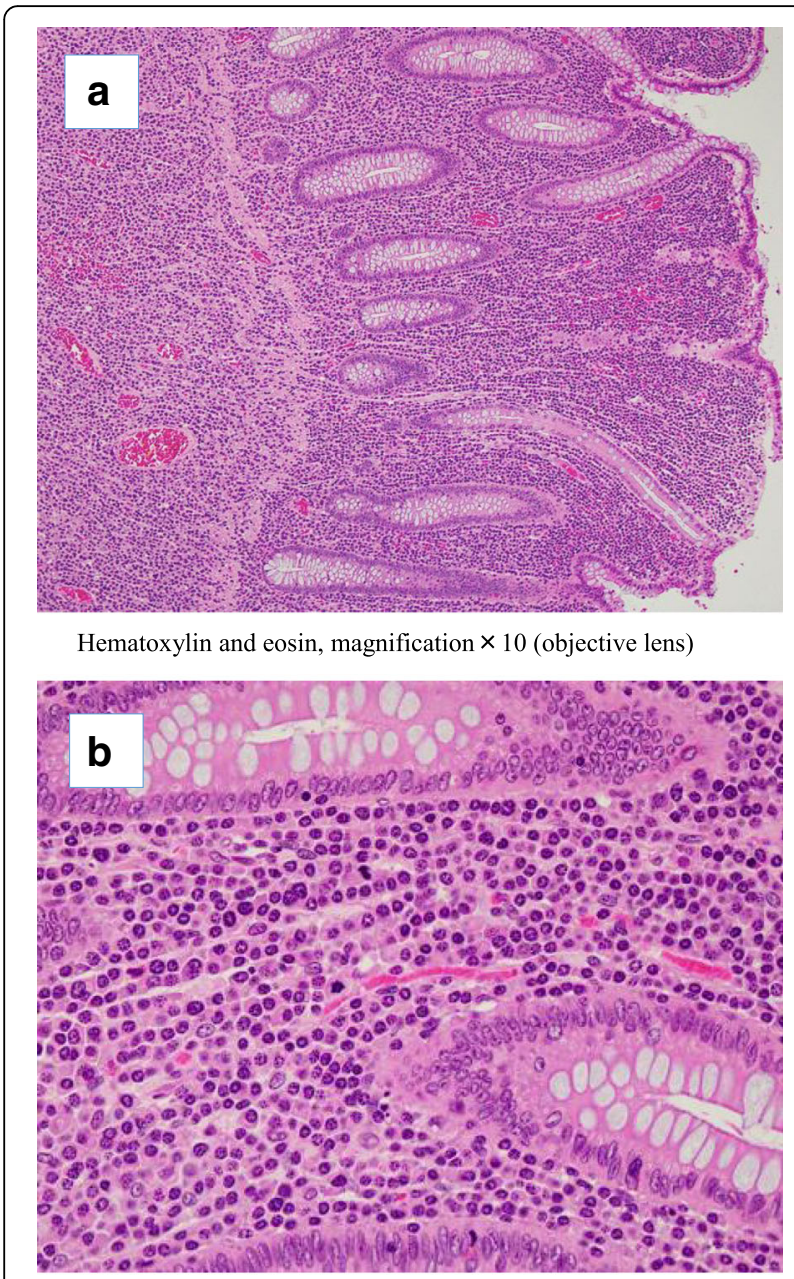

Hematoxylin and eosin, magnification $\times 20$ (objective lens)

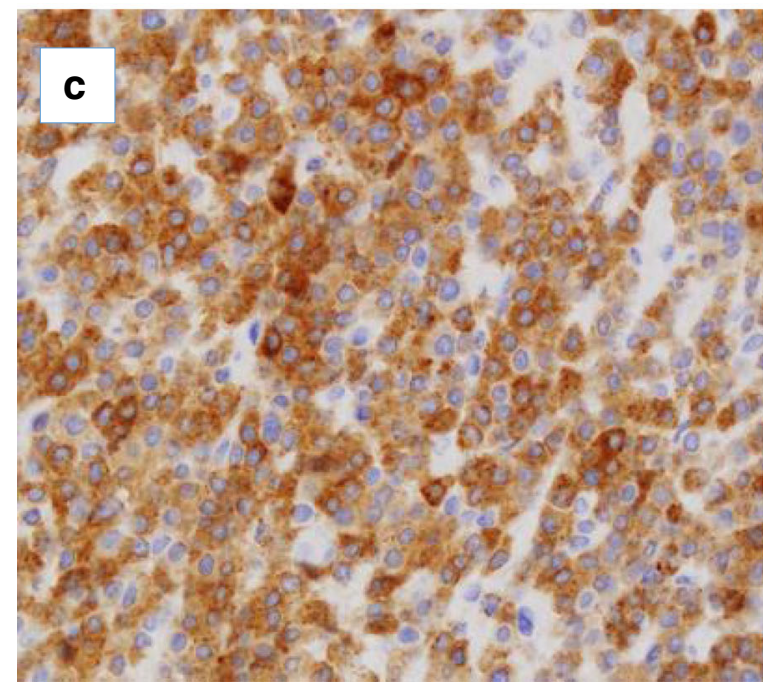

CD79a, magnification $\times 40$ (objective lens)

Fig. 3 Microscopic examination. a, b Histopathologic examination of the resected tumor shows diffuse proliferation of atypical plasma cells (hematoxylin and eosin). c Immunohistochemical examination shows CD79a staining

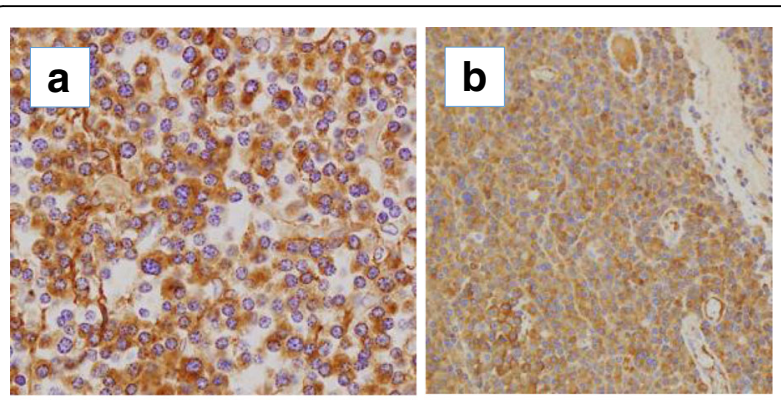

IgG, magnifyication $\times 40$ (objective lens)

$\lambda$-LC, magnifyication $\times 20$ (objective lens)

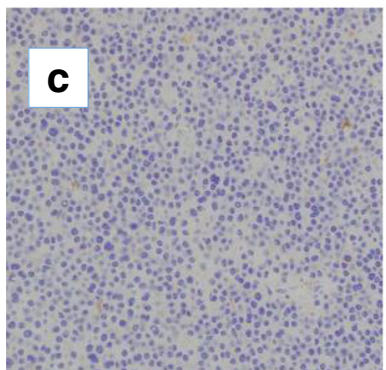

$\kappa$-LC, magnifyication $\times 20$ (objective lens)

Fig. 4 Immunohistochemical examination. a, b In situ hybridization shows that most of the tumor expresses immunoglobulin $\mathrm{G}$ and lambda light chain mRNA. IgG, immunoglobulin $G ; \lambda$-LC, lambda light chain. $\mathbf{c}$ In contrast, there is no expression of kappa light chain mRNA. $\mathrm{K}-\mathrm{LC}$, kappa light chain

electrophoresis, and normal bone marrow biopsy [4]. Our present case met these criteria.

Alexiou et al. [5] reported that extramedullary plasmacytoma most often occurs in the nasopharynx or upper respiratory tract $(82.2 \%)$. Only $17.8 \%$ of cases involve the gastrointestinal tract. The stomach and small intestine are the most commonly involved sites in the gastrointestinal tract. Primary isolated extramedullary plasmacytoma of the colon is extremely rare, occurring in only 0 . $028 \%$ of cases [5]. Therefore, its clinical features and prognosis are not well known.

The clinical presentation of extramedullary plasmacytoma of the colon is variable and may include abdominal pain, intestinal bleeding, and diarrhea. Gabriel and Savu [6] reported a rare case in which an extramedullary plasmacytoma was found with ileocecal junction perforation secondary to colonoscopic injury. This is the only previous report to describe extramedullary plasmacytoma with gastrointestinal perforation (Table 2).

In the present case, we were unable to determine the cause of the perforation by pathologic examination. We consider that the tumor was necrosed and perforated; otherwise, as the tumor grew, the intestinal internal pressure increased, resulting in perforation of the sigmoid colon.

Postoperative chemotherapy has no effect on the course of extramedullary plasmacytoma. Our patient did not undergo postoperative adjuvant chemotherapy, and 
Table 2 Well-documented cases of plasmacytoma of the colon

\begin{tabular}{|c|c|c|c|c|c|}
\hline Author/year & Sex & Age (years) & Location & Clinical features & Therapy \\
\hline Vasiliu and Popa/1928 & $\mathrm{F}$ & 47 & Sigmoid & $\begin{array}{l}\text { Anorexia, epigastric pain, } \\
\text { glandular enlargement }\end{array}$ & $?$ \\
\hline Brown and Liber/1939 & M & 57 & Colon, rectum & Rectal discomfort & $?$ \\
\hline Hampton and Gandy/1957 & $\mathrm{F}$ & 43 & Rectum & Rectal pain and bleeding & Rectosigmoid resection \\
\hline Miller/1970 & M & 35 & Cecum & Anemia & Right hemicolectomy \\
\hline William/1970 & M & 84 & Cecum & Anemia & Right hemicolectomy \\
\hline Neilson/1972 & $\mathrm{F}$ & 82 & Sigmoid & Pain & Resection \\
\hline Wing/1975 & $\mathrm{F}$ & 82 & Ascending colon & Pain & Right hemicolectomy \\
\hline Shaw/1976 & $\mathrm{F}$ & 47 & Cecum & Diarrhea & Resection \\
\hline Staples/1977 & M & 61 & Sigmoid & $\begin{array}{l}\text { Incidental operative } \\
\text { finding }\end{array}$ & Resection \\
\hline Daniel/1977 & M & 21 & Descending colon & Pain, nausea, vomiting & Left hemicolectomy \\
\hline Allion/1977 & M & 61 & Sigmoid & None & Sigmoid colectomy \\
\hline Adekunle/1978 & M & 35 & Cecum & Pain & Right hemicolectomy \\
\hline Terrence/1982 & $\mathrm{F}$ & 20 & Transverse colon & Pain, rectal bleeding & Transverse colon resection \\
\hline Sidani/1985 & M & 52 & Sigmoid & $\begin{array}{l}\text { Pain, } \\
\text { rectal bleeding }\end{array}$ & Resection \\
\hline Rechard/1987 & M & 77 & Cecum & $\begin{array}{l}\text { Weight loss, anemia, pain, } \\
\text { fecal occult blood }\end{array}$ & Right hemicolectomy \\
\hline Saverio Ligato/1996 & M & 45 & Hepatic flexure of the colon & Anemia & Extended right hemicolectomy \\
\hline Holland/1997 & M & 62 & Sigmoid colon & Pain & Sigmoid colectomy \\
\hline Lattuneddu/2004 & M & 86 & Sigmoid colon & $\begin{array}{l}\text { Pain, rectal bleeding, } \\
\text { asthenia }\end{array}$ & $\begin{array}{l}\text { Segmental resection of the } \\
\text { left colon }\end{array}$ \\
\hline Gupta/2007 & M & 42 & Diffuse colon & Diarrhea & Subtotal colectomy \\
\hline Jones/2008 & M & 65 & Sigmoid colon & Dysuria, abdominal pain & Sigmoid colon resection \\
\hline Jone/2008 & M & 57 & Sigmoid colon & Fatigue, melena & Hartmann resection \\
\hline Doki/2008 & M & 64 & Ascending colon & Pain & $\begin{array}{l}\text { Right hemicolectomy, lymph } \\
\text { node dissection, excision of } \\
\text { Gerota's fascia, partial resection } \\
\text { of the posterior portion of } \\
\text { the liver }\end{array}$ \\
\hline Collado Pacheco/2009 & M & 74 & Right colon & $\begin{array}{l}\text { Diarrhea, pain, rectal } \\
\text { bleeding }\end{array}$ & $?$ \\
\hline Kodani/2011 & M & 42 & Sigmoid & Fecal occult blood & $\begin{array}{l}\text { Endoscopic submucosal } \\
\text { resection }\end{array}$ \\
\hline Nakagawa/2011 & $\mathrm{F}$ & 84 & Cecum and rectum & Medical examination & $\begin{array}{l}\text { Endoscopic submucosal } \\
\text { resection }\end{array}$ \\
\hline Lee/2013 & M & 45 & Transverse colon & Pain & Extended left hemicolectomy \\
\hline Zihni/2013 & M & 54 & Descending colon & Pain and weakness & $\begin{array}{l}\text { Left hemicolectomy and small } \\
\text { intestinal resection }\end{array}$ \\
\hline $\mathrm{Han} / 2014$ & M & 49 & Transverse colon & Pain & Left hemicolectomy \\
\hline Emmanuel/2014 & M & 62 & Cecum & $\begin{array}{l}\text { Perforation during } \\
\text { diagnostic colonoscopy }\end{array}$ & Right hemicolectomy \\
\hline Parnel/2015 & $\mathrm{F}$ & 72 & Right colon & $\begin{array}{l}\text { Fatigue, light-headedness, } \\
\text { dyspnea, dark stool }\end{array}$ & $\begin{array}{l}\text { Right hemicolectomy Distal } \\
\text { ileal resection }\end{array}$ \\
\hline
\end{tabular}

$F$ female, $M$ male 
she has had no relapse to date. However, careful followup is required.

Because primary isolated extramedullary plasmacytoma in the colon is very rare, the clinical course, treatment guidelines, and prognosis remain unclear. Further study of the clinical features of primary isolated extramedullary plasmacytoma of the colon is necessary to ensure that adequate treatment is administered.

\section{Conclusions}

We have described a rare case of extramedullary plasmacytoma of the gastrointestinal tract with perforation of the sigmoid colon. In this case, the prognosis was good because of appropriate treatment involving early surgery.

\section{Acknowledgements \\ The authors would like to thank Angela Morben, DVM, ELS, from Edanz \\ Group (www.edanzediting.com/ac) for editing a draft of this manuscript.}

\section{Funding}

This study did not receive any specific grant from funding agencies in the public, commercial, or not-for-profit sectors.

\section{Authors' contributions}

FK wrote the final manuscript and performed the literature search. KD supervised the writing of the manuscript. $\mathrm{HI}$ and TO performed the surgery.

All authors read and approved the final manuscript.

\section{Consent for publication}

Written informed consent was obtained from the patient for the publication of this report and any accompanying images.

\section{Competing interests}

The authors declare that they have no competing interests.

\section{Publisher's note}

Springer Nature remains neutral with regard to jurisdictional claims in published maps and institutional affiliations.

\section{Author details}

Department of Gastroenterological Surgery, Nobeoka Hospital, 2-1-10 Shinkoji, Nobeoka, Miyazaki 882-0835, Japan. ²Department of

Gastroenterological Surgery, Graduate School of Medical Science, Kumamoto University, Kumamoto, Japan.

Received: 1 August 2017 Accepted: 22 March 2018

Published online: 04 April 2018

\section{References}

1. Liebross RH, Ha CS, Cox JD, Weber D, Delasalle K, Alexanian R. Clinical course of solitary extramedullary plasma. Radiother Oncol. 1999;52:245-9. https://doi.org/10.1016/S0167-8140899900114-0.

2. Hampton JM, Gandy JR. Plasmacytoma of the gastro-intestinal tract. Ann Surg. 1957:145:415-22

3. Asselah F, Crow J, Slavin G, Sowter G, Sheldon C, Asselah H. Solitary plasma of the intestine. Histopathology. 1982:6:631-45.

4. Meritt JW Jr. Plasmacytoma of gastrointestinal tract. Ann Surg. 1955;142:881-8.

5. Alexiou C, Kau RJ, Dietzfelbinger H, Kremer M, Spiess JC, Schratzenstaller B, et al. Extramedullary plasmacytoma: tumor occurrence and therapeutic concepts. Cancer. 1999;85:2305-14.

6. Gabriel EM, Savu M. Discovery of a rare ileocecal plasmacytoma. J Surg Case Rep 2014(3):rju016. doi:https://doi.org/10.1093/jscr/rju016.

\section{Submit your manuscript to a SpringerOpen ${ }^{\circ}$ journal and benefit from:}

- Convenient online submission

Rigorous peer review

- Open access: articles freely available online

- High visibility within the field

Retaining the copyright to your article 